\title{
THE COMPARISON OF THE RESULTS OF LASER SCANNING AND CLASSICAL SURVEYING METHODS OF MEASURING THE AREA AND VOLUME IN THE CHAPEL OF ST. KINGA IN THE SALT MINE OF BOCHNIA
}

\section{Jadwiga MACIASZEK, Dominik MADUSIOK \& Wojciech MATWIJ}

\author{
AGH University of Science and Technology, \\ Faculty of Mining Surveying and Environmental Engineering; \\ al. Mickiewicza 30, 30-059 Krakow, Poland; \\ e-mail:maciasze@agh.edu.pl,dominusss@gmail.com,matwij@agh.edu.pl
}

\begin{abstract}
Providing a long durability of the historic salt mine of Bochnia demands proper observations, analyses and drawing conclusions based on them and leading to recognising and the assessment of a specific behaviour of the rock mass and the effectiveness of the protection from mining damage. The studies of the rock mass and surface deformation are carried out by the mine based on the results of the observations made with the methods of surveying. These observations include, among others, the measurements of the height of benchmarks stabilized on the surface and rock mass, the measurements of linear convergence (on the established vertical and horizontal bases in selected chambers of the mine); and since 2003 the attempts have been made to apply total stations and laser scanners to document the selected chambers. The article presents test studies on laser scanning carried out in the chapel of St. Kinga in the Bochnia Salt Mine in 2007 and 2013 (Fig. 1). They showed high accuracy of the scanning method both in the positioning of points of the salt excavation, in modelling, as well as calculation of the area of any cross-section (Fig. 2) and the volume of chambers of complicated shapes (Fig. 3). The carried out accuracy studies, analyses and comparisons were used in the calculation of the area convergence for the chapel of St. Kinga in the Bochnia Salt Mine. They make base for the calculation of volume do convergence in the near future.
\end{abstract}

Key words: mining deformations, Salt Mine Bochnia, area convergence, laser scanning 


\section{INTRODUCTION}

Mining headings convergence is a measurable ratio depicting the process of post-mining headings closure, signalling a rock fall threat of a mining heading itself and its environment. That is why it is being researched in Polish salt mines, in particular the ones being historic monuments, where the good condition of chamber excavations used for tourist purposes is a priority issue. Until now linear convergence has been measured, on specially established horizontal and vertical bases (vertical and horizontal linear convergence, in specified directions). Line convergence measurement is done with the use of special extensometers (in shelves) or convergence meters (in chambers) in the mine of Kłodawa, with precise levelling in the mine of Bochnia or with two steel pipes anchored in the floor or the ceiling so that one is inserted into the other. The length is read with a millimetre ruler and a micrometer sensor with the resolution of $0.01 \mathrm{~mm}$ (May 2012). Devices of such a type are used in Inowrocław and Wieliczka (the Michałowice chamber). Cyclical measurements of linear convergence are used to develop a convergence model in a two- and three-dimensional space (area and volume convergence) with the use of mathematical modelling. This traditional method of measuring and modelling area and volume convergence resulted from the lack of its direct measurement possibility. The attempts to use photogrammetric methods ended in failure due to their low precision. From 2003 on, the research has been carried upon the use of laser scanning in surveying, monitoring, visualization and examining area and volume convergence in historic salt mines (Maciaszek 2008).

The usability of laser scanning in surveying and visualising historic salt chambers is incontestable. The resultant numerical spatial model of the scanned object provides for additional possibilities no other measurement method has offered so far. A multi-million "cloud of points" covers the whole object with piquets, the distance between them being several millimetres, so with huge confidence we can say that laser scanning allows for creating the object's quasi-continuous model. Comparing two models developed with this technology at different periods allowed for defining the deformations and strain of the whole chamber (St. Kinga's chapel in the salt mine of Bochnia) or its any section, which has not been possible in any way till now. Other research methods compare at most vertical cross-sections (very rarely, they were made only in St. Kinga's chapel in Wieliczka (Maciaszek 2008), but in most cases only the lengths of horizontal and vertical sections for calculating linear convergence (Kortas et al. 2004), which has been discussed above. The need and purposefulness of commencing research on the evaluation of possibility and scope of applying laser scanning in tracking the deformation process in real environment in historic salt mines is important, because this new technology has been developing rapidly, measurements are safe, done very quickly and the modelling and calculation software is more and more precise. That is why one should still test this technology in order to define its scope of interest.

The historic chapel of St. Kinga in the salt mine of Bochnia (Fig. 1A) located at the depth of $212 \mathrm{~m}$ served as the test field. The chamber's maximum dimensions are: N-S direction $26.2 \mathrm{~m}$, W-E direction $18.2 \mathrm{~m}$, height: $6.5 \mathrm{~m}$. This chamber's measurement was performed in 2007 with a VX scanning tachymeter (by Trimble), obtaining 47,963 thousand research points. Additionally a measurement of seven vertical cross-sections was performed (Fig. 1B) 
with a precise mirror-free Leica TCR 1101 tachymeter (for which a special software was written, allowing for an automated measurement of vertical cross-sections in the telescope's two positions at any interval of the vertical angle - Owerko T.) A very popular mirror-free tachymeter, Leica TCR 1101 precision tachymeter, was used in the test research of the chamber ceiling' irregular surface with the tachymetric method, obtaining 273 piquets. A repeated measurement of the chamber was repeated after six years, in 2013. A FARO Focus 3D laser scanner as used in surveying measurement, obtaining ca $150 \mathrm{M}$ measurement points. A monitoring cross-section passing through the points $5 \mathrm{a}$ and 6000 (direction N-S) was performed with the Leica TCR 1101 precision tachymeter (the same as in 2007) and delivered 314 points.
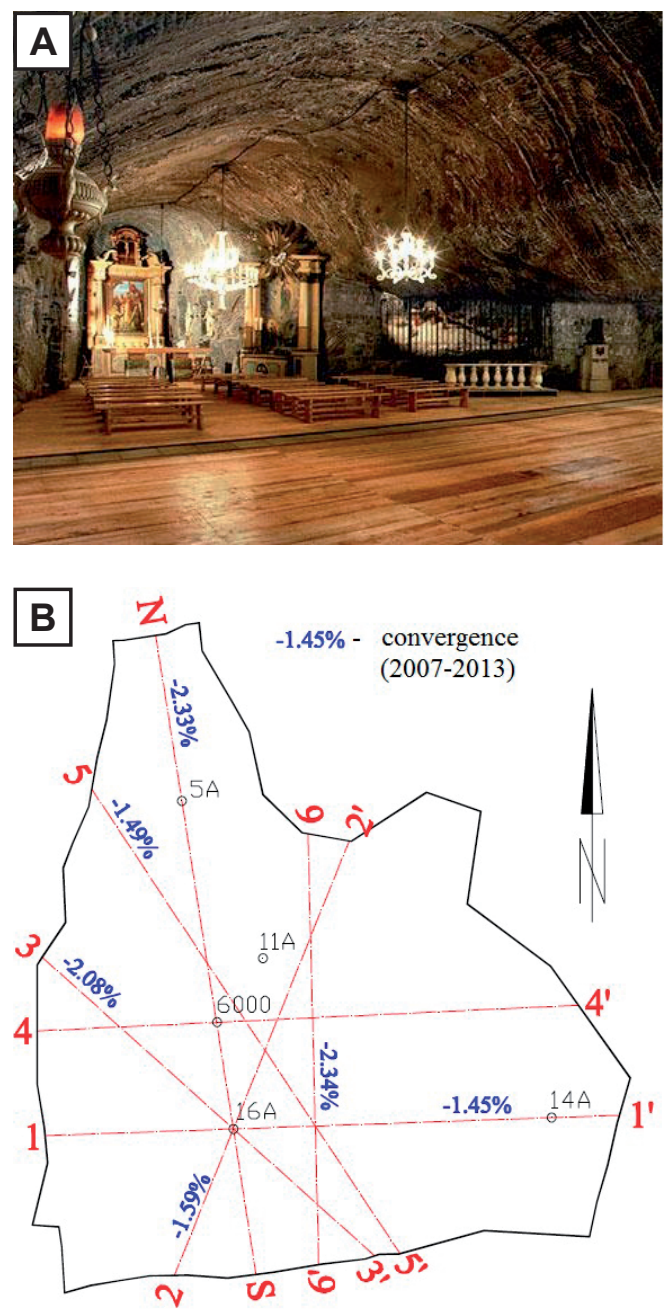

Fig. 1. The chapel of St. Kinga: A) general view; B) cross-sections to study convergence 
The following values were established as result of the research:

- points location precision ( $X, Y, Z$ coordinates ) with a TCR tachymeter, a VX scanning tachymeter and a Faro Focus 3D laser scanner,

- the cross-sections area and the chamber volume measurement precision,

- the chamber's area convergence in 2007-2013,

- the chamber's precise volume (as a whole and of the part used in further research) in 2013.

\section{POINTS POSITIONING PRECISION ON THE CHAMBER'S WALLS AND CEILING}

The companies manufacturing tachymeters and laser scanners specify their distance and angles measurement precision, but we do not know the conditions at which these precision values were determined. That is why precision values determined with new equipment in real conditions (in comparison with the values of the most precise equipment compared earlier) allow for performing a comparative analysis and interpreting it (Maciaszek et al. 2007).

The observations included:

- vertical cross-section (seven cross-sections in 2007 and one cross-section in 2013 Fig. 1B) performed with a precision tachymeter, to which all measurement results were compared in 2007 and 2013,

- the chamber's ceiling tachymetric measurements with a TCR tachymeter (273 points) in 2007 ,

- laser scanning with a VX scanning tachymeter in 2007 (47,963 points),

- laser scanning with a Faro Focus 3D laser scanner in 2013 (ca 150 M points).

The following values were determined by way of calculations:

- all points' coordinates in the local Bochnia's coordinate system,

- points position errors following the formula (1) (for 2013) and (2) (for 2007):

$$
\begin{aligned}
& m_{d}= \pm \sqrt{\frac{[d d]}{n}} \\
& m= \pm \frac{\sum m_{d i}}{i}
\end{aligned}
$$

where:

$d$-a single difference between the measurement with a precision tachymeter and the modelling result,

$n$-the number of differences in the monitoring cross-section,

$i-$ the number of cross-sections. 
The obtained results are as follows:

a) a rare number of points (the ceiling model obtained from the TCR tachymeter) revealed the error of $m_{d}= \pm 71.1 \mathrm{~mm}$ (on the ceiling and the side walls),

b) a scanning tachymeter $m= \pm 19.7 \mathrm{~mm}$ (on the ceiling and the side walls),

c) a laser scanner $m_{d}= \pm 3.8 \mathrm{~mm}$ (on the ceiling, side walls and the floor covered with plank wood).

\section{Re. a)}

Too rare a number of point on an irregular surface of the chamber's ceiling did not allow for creating its precise model. That is why vertical cross-sections performed with a Leica TCR 1101 precision tachymeter ignored the points from a tachymetric measurement (dispersed points) and encountered only not too precise a model created on the basis of a small number of points. A high value of the differences from both measurements excludes the tachymetric method from a possibility of its being used for convergence tests (Maciaszek 2007).

\section{Re. b)}

Laser scanning made with a VX scanning tachymeter from one post allowed for the modellingof the chamber with a precision allowable for architectural objects $( \pm 20 \mathrm{~mm})$. This precision is sufficient for surveying and visualization, however, it is too low for convergence testing. Laser beams falling on the irregular ceiling and side walls at various angles provided a set of points differing in terms of precision. One may suspect that performing the measurement from 3 posts would improve this precision (Maciaszek 2007).

\section{Re. c)}

Points obtained in the scanning performed in 2013 also reveal differences in precision. The chamber's floor is made of plank wood, of almost ideal smoothness and it reveals precision of $m_{d}= \pm 1.5 \mathrm{~mm}$, while the ceiling and side walls are made of salt, of coarse surface, cavities (manual salt mining) reveals the worst precision values, being $m_{d}= \pm 4.7 \mathrm{~mm}$ on the average.

The three measurement methods reveal a visible improvement of results together with the increase of the positioned points number. Thus, it has been proven that the best measurement technology for such irregular areas or volumes like salt chambers where salt was mined by hand, is the laser scanning method. The professionals depart from photogrammetric methods used in mining in the past that require good lighting and building platforms in order to take good pictures. One should also mention that a measurement of ca $50 \mathrm{M}$ points with a resolution of several millimetres, with a FARO Focus 3D scanner, took 9 minutes. The measurement was made from six positions, which took less than an hour. The resultant cloud of points was then thickened by removing the points with the weakest reflection (the filtration on the basis of the signal reflection intensity). The volume of the thus obtained points file for each position was $90 \mathrm{MB}$ (ca $0.5 \mathrm{~GB}$ for the whole chamber). The scanning technology is still being perfected and increases its potential. Also scanners are of various precision. The distance 
measurement precision specified by the manufacturer of the Faro Focus 3D phase scanner is $\pm 2 \mathrm{~mm}$, while for the Surphaiser scanner it is $\pm 0.5 \mathrm{~mm}$ - this scanner was used to perform the measurements in the St. Kinga's chapel in Wieliczka in 2007 (Maciaszek 2008).

\section{PRECISION OF THE AREA DEFINITION}

Comparisons of vertical cross-sections made in 2007 and 2013 (Fig. 1B) with a Leica TCR 1101 precision tachymeter provide very detailed information. The whole chamber moves down, but the comparisons reveal that the chamber's ceiling moves on average twice as fast as the floor. The ceiling lowering on the average in 6 years is $10 \mathrm{~cm}$, while the floor $-5 \mathrm{~cm}$ (Fig. 3). This is proof of the existing chamber convergence (closure).

The area has been calculated for vertical sections (Fig. 1B), created on the basis of local monitoring measurements made with a precision tachymeter in 2007 and made from the volume's numeric model - following the measurements made with scanner in 2013. The calculations results are shown in Table 1.

\section{Table 1}

Mean areas on the tested cross-sections and area convergence in 2007-2013

\begin{tabular}{|c|c|c|c|c|c|c|}
\hline \multirow{2}{*}{ Section } & Tachymeter & Skanner & Tachymeter & \multicolumn{3}{|c|}{ Volume difference } \\
\cline { 5 - 7 } & 2007 & 2013 & 2013 & \multicolumn{3}{|c|}{ (volume convergence) } \\
\cline { 5 - 7 } & {$\left[\mathrm{m}^{2}\right]$} & {$\left[\mathrm{m}^{2}\right]$} & {$\left[\mathrm{m}^{2}\right]$} & {$\left[\mathrm{m}^{2}\right]$} & {$[\% / 6$ years $]$} & {$[\% /$ year $]$} \\
\hline N-S' & 124.11 & 121.78 & 121.63 & -2.33 & -1.88 & -3.13 \\
\hline $1-1^{\prime}$ & 65.91 & 64.95 & - & -0.96 & -1.45 & -2.42 \\
\hline $2-2^{\prime}$ & 71.78 & 70.64 & - & -1.14 & -1.59 & -2.65 \\
\hline $3-3{ }^{\prime}$ & 65.60 & 64.24 & - & -1.36 & -2.08 & -3.46 \\
\hline $5-5$ & 80.60 & 79.40 & - & -1.20 & -1.49 & -2.49 \\
\hline $6-6$, & 72.95 & 71.24 & - & -1.71 & -2.34 & -3.91 \\
\hline \multicolumn{3}{|c|}{ Average convergence for 6 years $=-1.81 \%$} \\
\hline
\end{tabular}

The table reveals that in 6 years at each vertical section the area was decreased (1.45-2.34\%). The standard deviation of the percentage area change is $\sigma= \pm 0.36 \%$. Accordingly, one may claim that the post-mining void closure is not uniform. The aim of further research will be to present the differentiation of closure (convergence) in various parts of the chamber.

The cross-section in the N-S direction was obtained in 2013 using two independent methods: following a multi-million points cloud modelling and following an independent measurement with a precision tachymeter. The comparison of it area in 2013 (made with a precision tachymeter and a scanner) reveal a high calculation precision and confirms the precision from 2007 (Fig. 2) made with the same instrument. 


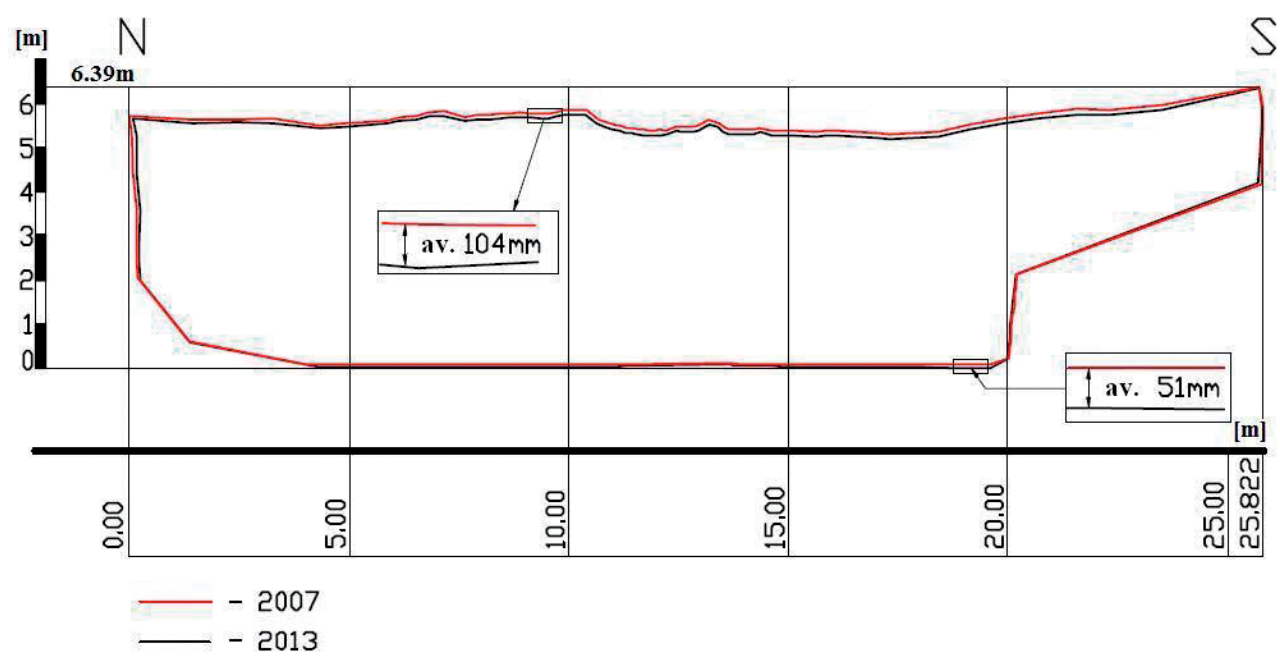

Fig. 2. Vertical cross-section N-S

The annual average area convergence of the chamber in 2007-2013 is, in individual cross-sections, from $-2.42 \%$ to $-3.91 \%,-3.01 \%$ on the average.

\section{CHAMBER VOLUME DETERMINATION}

With reference to heaps and dumps in open-pit mines (Rozporzadzenie Ministra Srodowiska... 2011) it is assumed that the difference between the doubled independent volume determination cannot exceed $12 \%$ for the volume up to $20,000 \mathrm{~m}^{3}$. For the historic salt mines in Wieliczka and Bochnia, where the majority of chambers is of smaller size, the assumed admissible difference for the doubled independent volume determination is up to $10 \%$. In the case of salt chambers the knowledge of volume is important, among other things, in order to determine the amount backfill needed to fill it or to forecast the terrain surface and the rock mass deformation. The most frequent method of determining the volume is the method of cross-sections:

$$
V=\sum_{i=1}^{n} \frac{p_{i}+p_{i+1}}{2} h_{i}+\frac{p_{1}}{2} h_{r p}+\frac{p_{n}}{2} h_{r k}
$$

where:

$p_{i}-$ the surface area of $i$-th cross-section,

$h_{i}-$ the assumed distance between the cross-sections $p_{i}$ and $p_{i+1}$,

$h_{r p}, h_{r k}$ - the distances between the first and the last cross-section to the floor and the ceiling (horizontal cross-sections) or the side walls (vertical cross-sections). 
One should note that a doubled independent volume calculation with the same method (formula (3)) contains the same measurement errors and the error of the same method of volume calculation.

The chamber model accepted as the input measurement for the volume calculation was the chamber model obtained on the basis of the point cloud changed in 2013 from scanning. This measurement should be regarded as a very precise one. A precision test was also conducted, consisting of an independent calculation of a significant part of the chamber (elements with the altar, pictures, chancel and sacristy were omitted). Also, side heading limitation was important here. That is why an envelope was created that will be used to limit the heading in the following years and to conduct an analyses within the same dimensions. Only such heading model preparation may serve for analyses, comparisons and calculating volume convergence. The cross-sections on the model were made on the (N-S) cross-section line, with intervals at $1 \mathrm{~m}$ (Fig. 3).

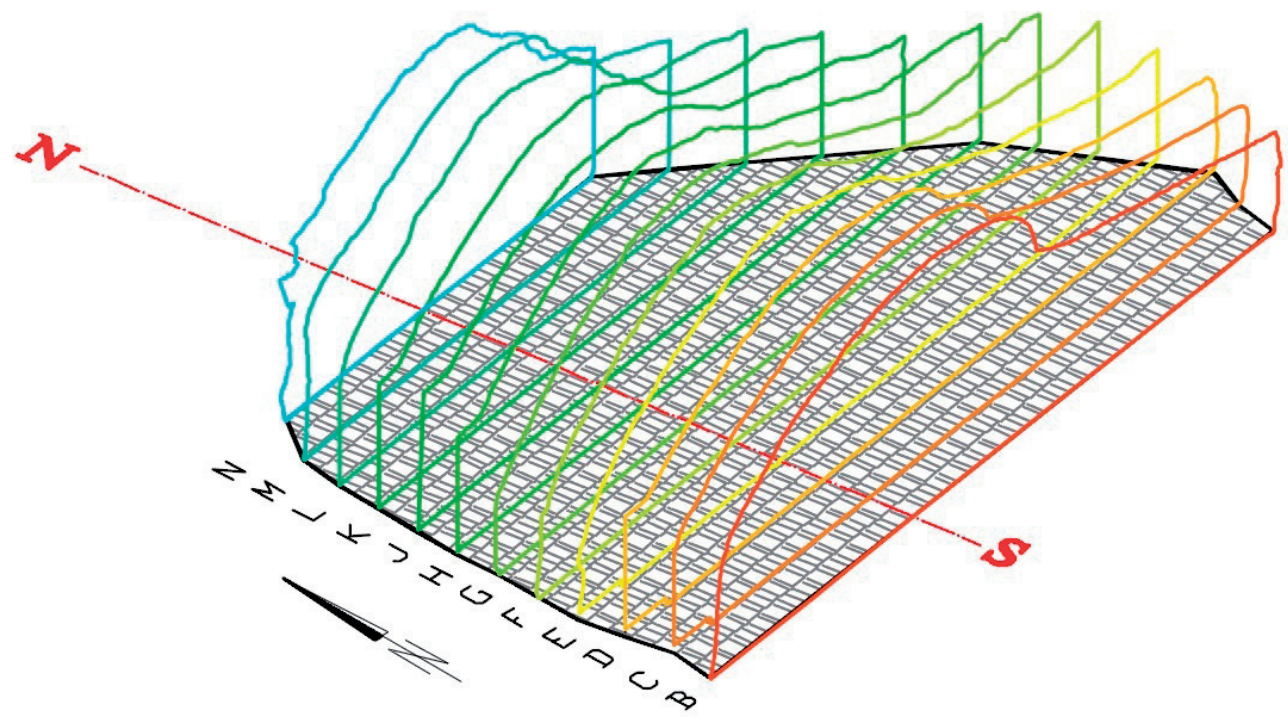

Fig. 3. Vertical cross-sections to calculate the volume of the studied part of the chapel of St. Kinga

The volume was calculated with two independent methods: a cross-section method $\left(672.21 \mathrm{~m}^{3}\right)$ and the algorithm included in Geomagic Qualify software $2012\left(672.72 \mathrm{~m}^{3}\right)$.

The chamber's total volume was also determined (including the chancel, the nativity scene, the part with the altar and other religious elements) that was $1154 \mathrm{~m}^{3}$.

Because of too small a volume calculation precision in 2007 (different envelope of the research part) determining volume convergence was not possible. 


\section{CONCLUSIONS}

1. The modern methods of observing the conditions of mining headings include laser scanning with scanning tachymeters and scanners. They are used to obtain, in a short time, a multi-thousand (in the case in a tachymeter measurement) or a multi-million (in the case of a scanner measurement) cloud of points. Using laser scanning allows for determining the position of any point on the heading point with a precision dependent on the measurement point density and the scanner precision. Thus, for the density of ca $2 \mathrm{M}$ points the point positioning precision was from $\pm 1.5 \mathrm{~mm}$ to $\pm 5 \mathrm{~mm}, \pm 3.8 \mathrm{~mm}$ on the average, while for the point density four times lower (the measurement with scanning tachymeter) it was $\pm 19.7 \mathrm{~mm}$. The measurement method allows for the creation of a quasi-continuous model of the heading that allows for implementing various engineering tasks and projects. However, for the future-oriented research of area and volume convergence of the heading, the most precise laser scanners should be used.

2. Comparison of the N-S cross-section area, determined by laser scanning with the Faro Fokus 3D scanner and the measurement with a Leica TCR 1101 precision tachymeter demonstrated the conformity of the obtained observation results, which proves a high precision of laser scanning and the possibility of using this technology to test area and volume convergence.

3. The observations made in St. Kinga's chapel in Bochnia demonstrated the occurrence of area convergence (specified on the basis of the chamber's vertical cross-sections), being on the average 3.01\% /year, however, its differentiation in various locations of the chamber (defined by the cross-sections location) was from $2.42 \%$ /year to $3.91 \%$ /year.

4. The volume of the chamber used in the research was calculated with the use of two independent methods: a cross-section method $\left(672.21 \mathrm{~m}^{3}\right)$ and the algorithm included in Geomagic Qualify software $2012\left(672.72 \mathrm{~m}^{3}\right)$. The automatic method includes all irregular locations ignored by the cross-section method. The difference between two independent methods is $0.08 \%$, which proves the very high precision of calculating the volume of such irregular volumes, such as St. Kinga's chapel.

5. Laser scanning is a technology that is exceptionally quick and allows for obtaining a large amount of data in a short time periods. At the same time it is an optimum technology for calculating area and volume convergence that allows for the verification of theoretical models used for forecasting the rock mass deformation. Further implementation of this technology in the mining heading surfing and testing area and volume convergence is recommended.

\section{SUMMARY}

Assuring a long period of durability for the historic salt mine in Bochnia needs running appropriate observations, analyses and using them as the basis for the conclusions that aim at determining and evaluating specific behaviour of the rock mass and efficiency of safety 
measures against mining dangers. The mine conducts research of the rock mass and the terrain surface deformation on the basis of the results of observations, made with geodesic methods. These observations include, among other things, measurements of the height of the benchmarks installed on the surface and in the rock mass, linear convergence measurements (on the established vertical and horizontal bases in the mine's selected chambers) and from 2003 on the attempts were carried to apply tachymeters and laser scanners in the selected chambers surveying. The paper presents a test research of laser scanning conducted in St. Kinga's chapel in the salt mine of Bochnia in 2007 and 2013 (Fig. 1). They proved a large precision of the scanning method, both in positioning the point of the salt mine heading, in modelling, as well as calculating the area of any cross-section (Fig. 2) and the volume of chambers with complicated shapes (Fig. 3). The conducted precision research, analyses and comparisons were used in the calculations of area convergence for St. Kinga's chapel in the salt mine of Bochnia (Tab. 1), being on the average 3.01\%o/year, however, its differentiation in various locations of the chamber (defined by the cross-sections location) was from $2.42 \%$ /year to $3.91 \%$ /year.

The volume of the chamber used in the research was calculated with the use of two independent methods: a cross-section method $\left(672.21 \mathrm{~m}^{3}\right)$ and the algorithm included in Geomagic Qualify software $2012\left(672.72 \mathrm{~m}^{3}\right)$. The automatic method includes all irregular locations ignored by the cross-section method. The difference between two independent methods is $0.08 \%$, which proves a very high precision of calculating the volume of such irregular volumes, such as St. Kinga's chapel.

The measurements and calculations made in 2013 are the basis for calculating the chapel's volume convergence in the nearest period.

The article was written as a part of the statutory research no. 11.11.150.195.

\section{REFERENCES}

Kortas G., Szewczyk J. \& Toboła T., 2004. Ruch górotworu i powierzchni w otoczeniu zabytkowych kopalń soli. Wydawnictwo IGSiE, Kraków.

Maciaszek J. (manager), 2007. Badanie możliwości stosowania skanerów laserowych do inwentaryzacji, wizualizacji i monitoringu obiektów inżynierskich i górniczych. Projekt badawczy nr 4T12E 05729 [unpublished].

Maciaszek J. \& Gawałkiewicz R., 2007. Badanie dokładności tachimetrów i skanerów laserowych w warunkach laboratoryjnych i polowych. Zeszyty Naukowe Politechniki Ślaskiej, Górnictwo, 278, Gliwice.

Maciaszek J., 2008. Skanowanie laserowe jako nowa technologia inwentaryzacji i wizualizacji zabytkowych komór solnych. Gospodarka Surowcami Mineralnymi, 24, 3/2, $197-210$. 
Maj A., 2012. Convergence of gallery workings in underground salt mines. Archives of Mining Sciences, Monograph, 14, 1-112.

Rozporzadzenie Ministra Środowiska z dnia 22 grudnia 2011 r. w sprawie dokumentacji mierniczo-geologicznej. Dz.U. 2011, nr 291, poz. 1713.

\section{Streszczenie}

Zapewnienie długiego okresu trwałości zabytkowej Kopalni Soli Bochnia wymaga prowadzenia odpowiednich obserwacji, analiz i formułowania na tej podstawie wniosków dotyczących rozpoznania i oceny swoistych zachowań górotworu i skuteczności zabezpieczeń przed zagrożeniami górniczymi. Badania deformacji górotworu i powierzchni terenu kopalnia prowadzi na podstawie rezultatów obserwacji wykonanych metodami geodezyjnymi. Do tych obserwacji należą między innymi pomiary wysokości reperów zastabilizowanych na powierzchni i w górotworze czy pomiary konwergencji liniowej (na założonych bazach pionowych i poziomych w wybranych komorach kopalni). Od 2003 r. prowadzone były także próby zastosowania tachimetrów i skanerów laserowych do inwentaryzacji wybranych komór. Artykuł przedstawia badania testowe skaningu laserowego przeprowadzone w kaplicy św. Kingi w KS Bochnia w latach 2007 i 2013 (Fig. 1). Wykazały one dużą dokładność metody skaningowej zarówno w pozycjonowaniu punktów na wyrobisku solnym, w modelowaniu, jak i w obliczaniu powierzchni dowolnego przekroju (Fig. 2) oraz objętości komór o skomplikowanych kształtach (Fig. 3). Przeprowadzone badania dokładnościowe, analizy i porównania posłużyły do obliczenia konwergencji powierzchniowej w kaplicy św. Kingi (Tab. 1). Wartość konwergencji wyniosła średnio 3,01\%o/rok, przy czym jej zróżnicowanie w różnych miejscach komory (określonych położeniem przekrojów) wyniosło od 2,42\%o/rok do $3,91 \%$ o/rok.

Objętość części komory wykorzystanej do badań obliczono dwoma niezależnymi metodami: metodą przekrojów $\left(672,21 \mathrm{~m}^{3}\right)$ i automatycznie algorytmem zawartym w programie Geomagic Qualify $2012\left(672,72 \mathrm{~m}^{3}\right)$. Metoda automatyczna uwzględnia wszystkie nieregularne miejsca pomijane w metodzie przekrojów. Różnica pomiędzy wynikami uzyskanymi dwoma niezależnymi metodami obliczeń wynosi $0,08 \%$, co świadczy o bardzo wysokiej dokładności obliczania objętości tak nieregularnych brył jak kaplica św. Kingi.

Pomiary i obliczenia wykonane w 2013 r. są podstawą do obliczenia konwergencji objętościowej kaplicy w najbliższym okresie. 